\title{
Cancer and Virtual Reality Vr, the Great Challenge of The Century
}

\section{SAKHRI Selma épse BOULHART}

Head of medical oncology service - Laghouat- Algeria

Corresponding Author: SAKHRI Selma épse BOULHART, Head of medical oncology service - Laghouat- Algeria.

Received date: December 01, 2021; Accepted date: December 27, 2021; Published date: January 04, 2022

Citation: SAKHRI Selma épse BOULHART (2022) Cancer and Virtual Reality Vr, the Great Challenge of The Century. J. Archives of Medical Case Reports and Case Study. 5(1); DOI: 10.31579/2692-9392/0101

Copyright: () 2022 SAKHRI Selma épse BOULHART, This is an open access article distributed under the Creative Commons Attribution License, which permits unrestricted use, distribution, and reproduction in any medium, provided the original work is properly cited.

\section{Abstract \\ The number of new cases of cancer is constantly increasing around the world. The lengthening of life expectancy and therefore the aging of the population largely explain this increase in the number of cancers, in particular (prostate cancer in men, breast cancer in women, colorectal or gastric cancers)}

Keywords: persistence; transovarial; intratoracal; ae. Aegypti; ae. albopictus

\section{Introduction}

The number of new cases of cancer is constantly increasing around the world. The lengthening of life expectancy and therefore the aging of the population largely explain this increase in the number of cancers, in particular (prostate cancer in men, breast cancer in women, colorectal or gastric cancers). The diagnosis, the associated treatments as well as the more or less long-term sequelae represent a multitude of stressful situations. It has thus been shown that more than $10 \%$ of patients treated forcancer present the clinical symptoms of an anxiety disorder [1] and this prevalence reaches nearly $17.6 \%$, in patients living with cancer for more than two years. years [2].Virtual reality is a therapeutic aid, but it also has its place in the training of doctors in oncology and in cancer diagnosis.
Medical oncology as a whole and virtual reality havea promising future.

\section{Virtual reality for patients}

Virtual reality has found its place with patients as a therapeutic aid. For a large numberof pathologies, such as cancer, it is used because it is a revolutionary technology but above all gentle and without side effects. VR refers to the interactions between an individual and a computergenerated environ-ment stimulating multiple sensory modalities, including visual, or auditory experiences, The user's perception of reality is facilitated by the use of headsets (HMD, in glasses or helmets), (Figure 1).

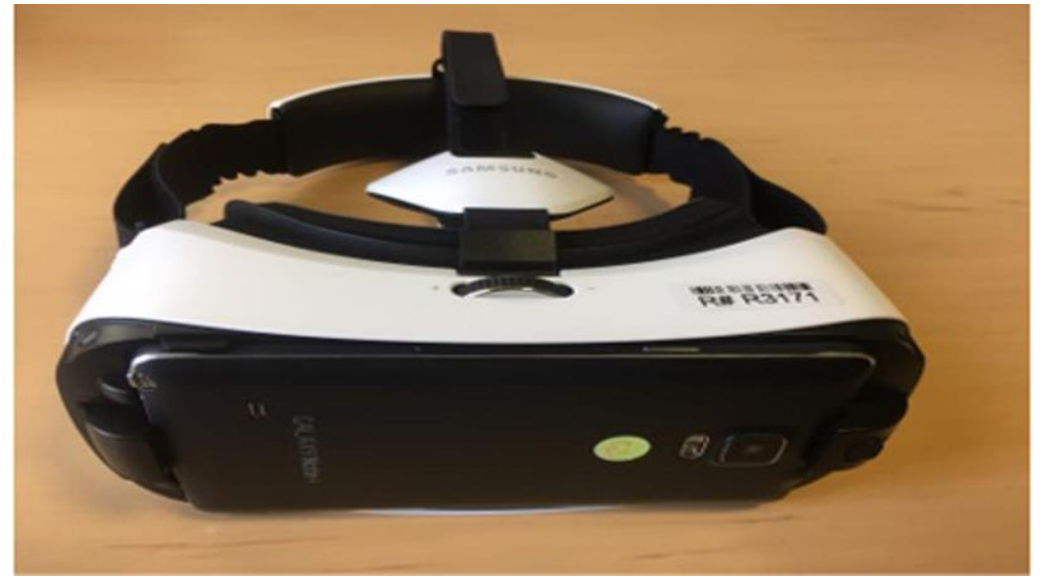

Figure 1: VR virtual reality headset 


\section{- To fight the pain}

VR is the most useful and used in this area. In developed countries, many oncology departments use virtual reality to help their patients fight against pain related to the disease or following a biopsy.

Almost half of hospital patients experience pain, a quarter of which is considered "un- bearable" [4]. The treatment of pain has traditionally been based on pharmacological management, including opioids, which can give inconsistent and suboptimal results. Therapeutic virtual reality (VR) has become an effective and non-pharmacological treatment modality for pain $[4,5]$. VR users wear a head-mounted display with a proxi- mity screen that creates a feeling of being transported to realistic threedimensional worlds (Fig. 1-2).

A proposed mechanistic theory of VR suggests that by stimulating the visual cortex while engaging other senses, VR acts as a distraction to limit the user's processing of nociceptive stimuli. [6].The ubiquity of high performance mobile computing has now reduced both the size and cost of virtual reality devices, enabling its use in everyday clinical environments. To date, VR has been used in many clinical settings in oncology, to help treat anxiety disorders, control pain, support physical rehabilitation, and distract patients during chemotherapy, [4, 6] Of Likewise, VR reduces pain and provides posi- tive distraction during procedures, such as intravenous line placements [6]

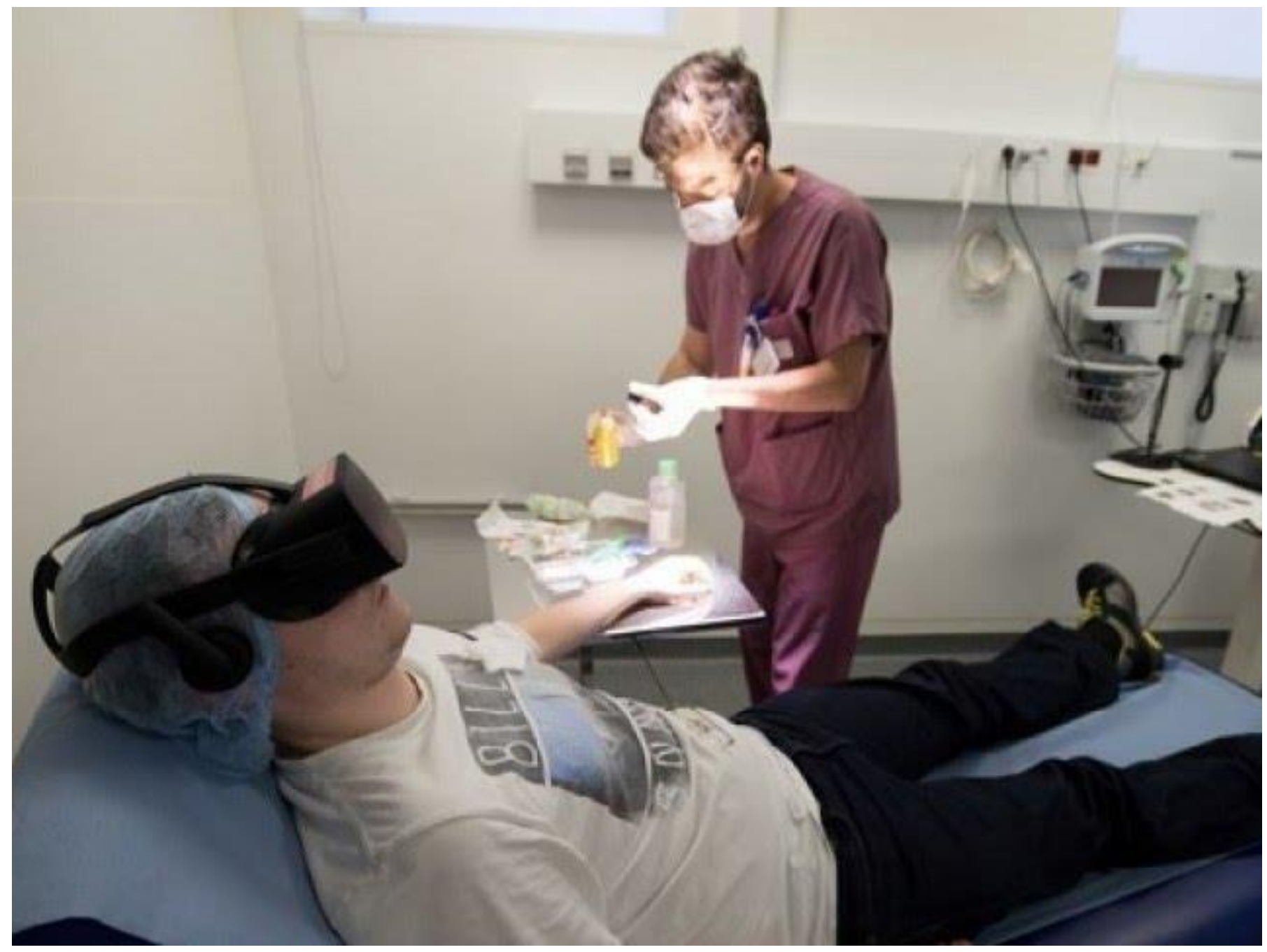

Figure 2: virtual reality for pain relief in hospitals Huffpost canada 2021

\section{To better manage a hospitalization}

VR is indeed an ideal tool to help adult patients and children to fight against stress but also trouble for chemotherapy sessions, it is a technology that will help them keep morale during these sessions.
Several controlled VR trials in hospitals have been published in the last 10 years:

\section{BOARD : Studies using virtual reality (VR) as a tool to improve medical conditions}




\begin{tabular}{|c|c|c|c|c|c|c|c|}
\hline $\begin{array}{l}\text { APPLICA- } \\
\text { TION }\end{array}$ & $\begin{array}{l}\text { AU- } \\
\text { THOR } \\
\text { (YEAR) }\end{array}$ & EQUIPMENT & $\begin{array}{l}\text { PARTICI- } \\
\text { PANTS }\end{array}$ & DESIGN & $\begin{array}{l}\text { RESULTS/EF } \\
\text { FI- CIENCY }\end{array}$ & $\begin{array}{l}\text { SECON- } \\
\text { ARY O ob- } \\
\text { ervations }\end{array}$ & $\begin{array}{l}\text { MEANQUA } \\
\text { - LITY }\end{array}$ \\
\hline $\begin{array}{l}\text { Eating disor- } \\
\text { ders/ Obesity }\end{array}$ & $\begin{array}{l}\text { Manzoni } \\
\text { et al } \\
(2009)\end{array}$ & $\begin{array}{l}\text { HMD: RV called } \\
\text { Green Valley } \\
\text { Psychologists as- } \\
\text { ked } \\
\text { Participant in } \\
\text { imagining an } \\
\text { environment } \\
\text { Similar. }\end{array}$ & $\begin{array}{l}\mathrm{N}=60 \text {; } \\
\text { female } \\
\text { Patients } \\
\text { talized hospi- } \\
\text { Weightloss }\end{array}$ & $\begin{array}{l}\text { Relaxation } \\
\text { workouts } \\
\text { Sessions ( } 4 \\
\text { per week) } \\
\text { over } 3 \text { weeks } \\
\text { ei- ther with } \\
\text { RV, traditio- } \\
\text { nal imagina- } \\
\text { tion } \\
\text { treatments, or } \\
\text { standard } \\
\text { hospital care }\end{array}$ & $\begin{array}{l}\text { At } 3 \text { months of fol- } \\
\text { low-up: } \\
\text { With RV /Relaxa- } \\
\text { tion training condi- } \\
\text { tions (RV and Ima- } \\
\text { ginative) helped re- } \\
\text { duce emotional ea- } \\
\text { ting (WELSQ; EOQ), } \\
\text { anxiety (STAI), } \\
\text { Depressive symp- } \\
\text { toms } \\
\text { (BDI); impro- } \\
\text { vements in self-ef- } \\
\text { ficacy (WELSQ) }\end{array}$ & Not applicable & 0.87 \\
\hline $\begin{array}{l}\text { Cognitive and } \\
\text { motor } \\
\text { Rehabilitation }\end{array}$ & $\begin{array}{l}\text { Larson et } \\
\text { al } \\
(2011)\end{array}$ & $\begin{array}{l}\text { VRROOM: a 3-D } \\
\text { Patients see vir- } \\
\text { tual objects supe- } \\
\text { rimposed on a Real } \\
\text { world }\end{array}$ & $\begin{array}{l}\mathrm{N}=18 ; \mathrm{pa}- \\
\text { tients with } \\
\text { Traumatic } \\
\text { brain } \\
\text { Injury } \\
\text { (TCC) } \\
1973 \\
\text { years Hos- } \\
\text { pitalized } \\
\text { patient }\end{array}$ & $\begin{array}{l}\text { Treatment } \\
\text { (with } 12 \\
\text { Four-minute } \\
\text { trials) }\end{array}$ & $\begin{array}{l}\text { Memory Impro- } \\
\text { vements Proces- } \\
\text { sing with haptic } \\
\text { cues helped im- } \\
\text { prove perfor- } \\
\text { mance vs. when } \\
\text { The clues were not } \\
\text { present }\end{array}$ & $\begin{array}{l}3 \text { participants } \\
\text { dropped out dueto } \\
\text { fatigue and eye } \\
\text { pain }\end{array}$ & 0.85 \\
\hline Pain distraction & $\begin{array}{l}\text { Li et al } 25 \\
(2011)\end{array}$ & $\begin{array}{l}\text { PlayMotion Sys- } \\
\text { tem } \\
\text { Without HMD; vi- } \\
\text { deo } \\
\text { Projectors capture } \\
\text { Body movements } \\
\text { and transforms } \\
\text { Walls at stake }\end{array}$ & $\begin{array}{l}\text { (8-16 years } \\
\text { old) } \\
\text { With cancer } \\
\text { in pediatric } \\
\text { oncology } \\
\text { Hong Kong; }\end{array}$ & $\begin{array}{l}\text { Pre- / } \\
\text { post-test } \\
\text { between } \\
\text { subjects } \\
\text { Design; } \quad 30 \\
\text { minutesjhad } \\
\text { therapeutic }\end{array}$ & \begin{tabular}{|lr} 
Less & depressed \\
Symptoms in the \\
experimental group \\
after 1 week
\end{tabular} & Not applicable & \\
\hline
\end{tabular}

\section{- For cancer patients in palliative care}

Virtual reality is indicated for anxious patients:

There are many anxiety-generating situations in palliative care (announcement of di- sease progression, care, chemotherapy sessions, radiotherapy, etc.) Often linked to anxiety attacks, the associated pains wake up or are increased. The use of head- phones could therefore soothe these patients by diverting their attention, and thus re- duce the pain crisis.

The virtual reality headset can help prevent pain:
Linked to certain treatments (installation of a peripheral venous route, Huber needle, indwelling catheter, carrying out blood gases, etc.) and during the repair of complex dressings (dilapidated, very painful tumor wounds, sources of anxiety, etc.).

This device can be used in addition to the usual therapies:

Like anxiolytics, neuroleptics or analgesics. It may also be of interest for patients who are resistant to taking medication. 


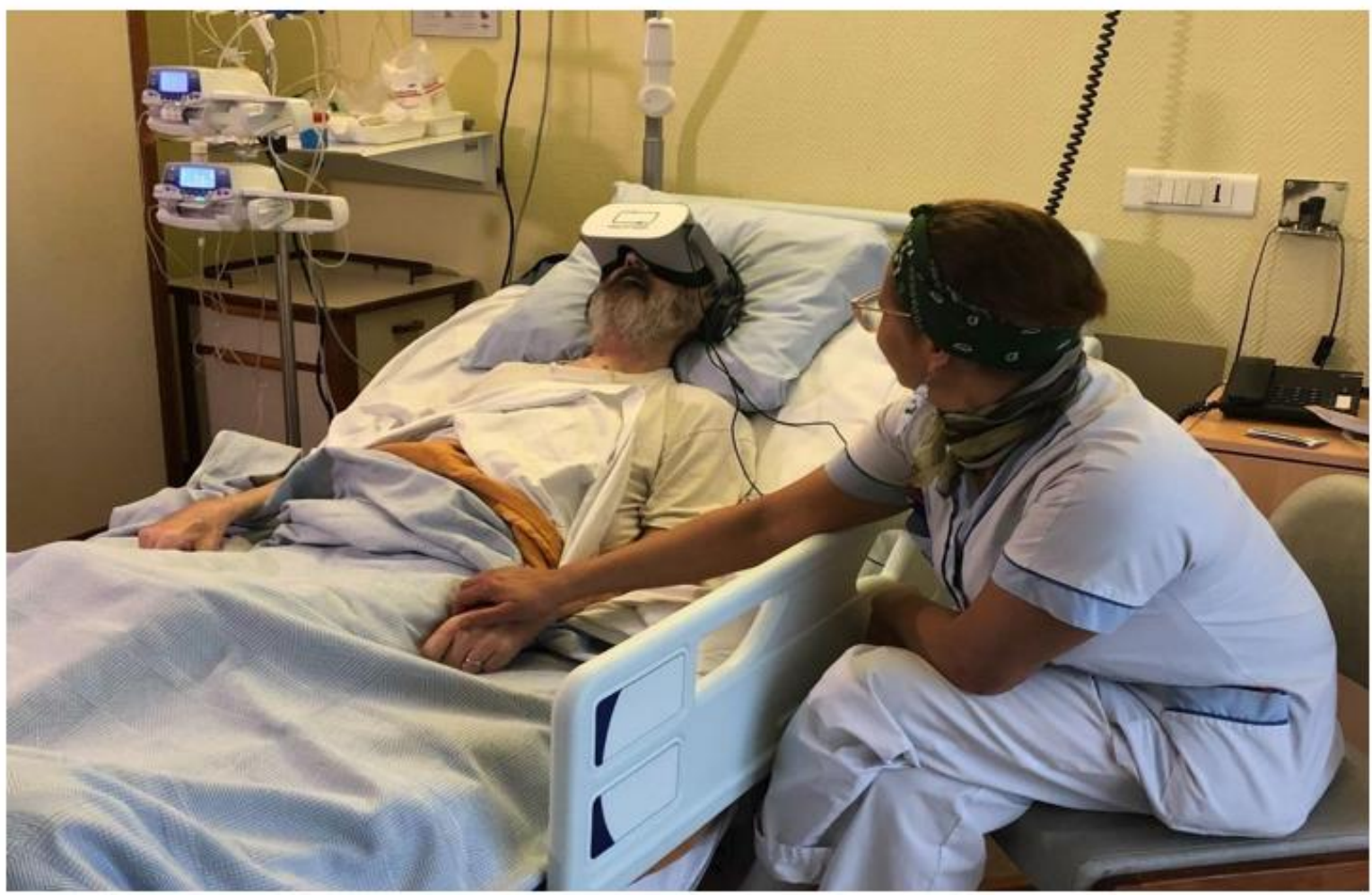

Figure 3: the virtual reality headset decreases the anxiety of the intensive care patient Healthy / mind 05/10/2021

\section{To train doctors}

\section{For medicine}

Its use in the field of health has focused on technical and educational applications (eg, preparation for surgery through simulations of surgical acts, medical evaluations), but also in therapeutic management - known as therapy by VR exposure - of certain pa- thologies such as cancer, anxiety disorders, psychosis, and certain forms of depres- sion) [7-8] 

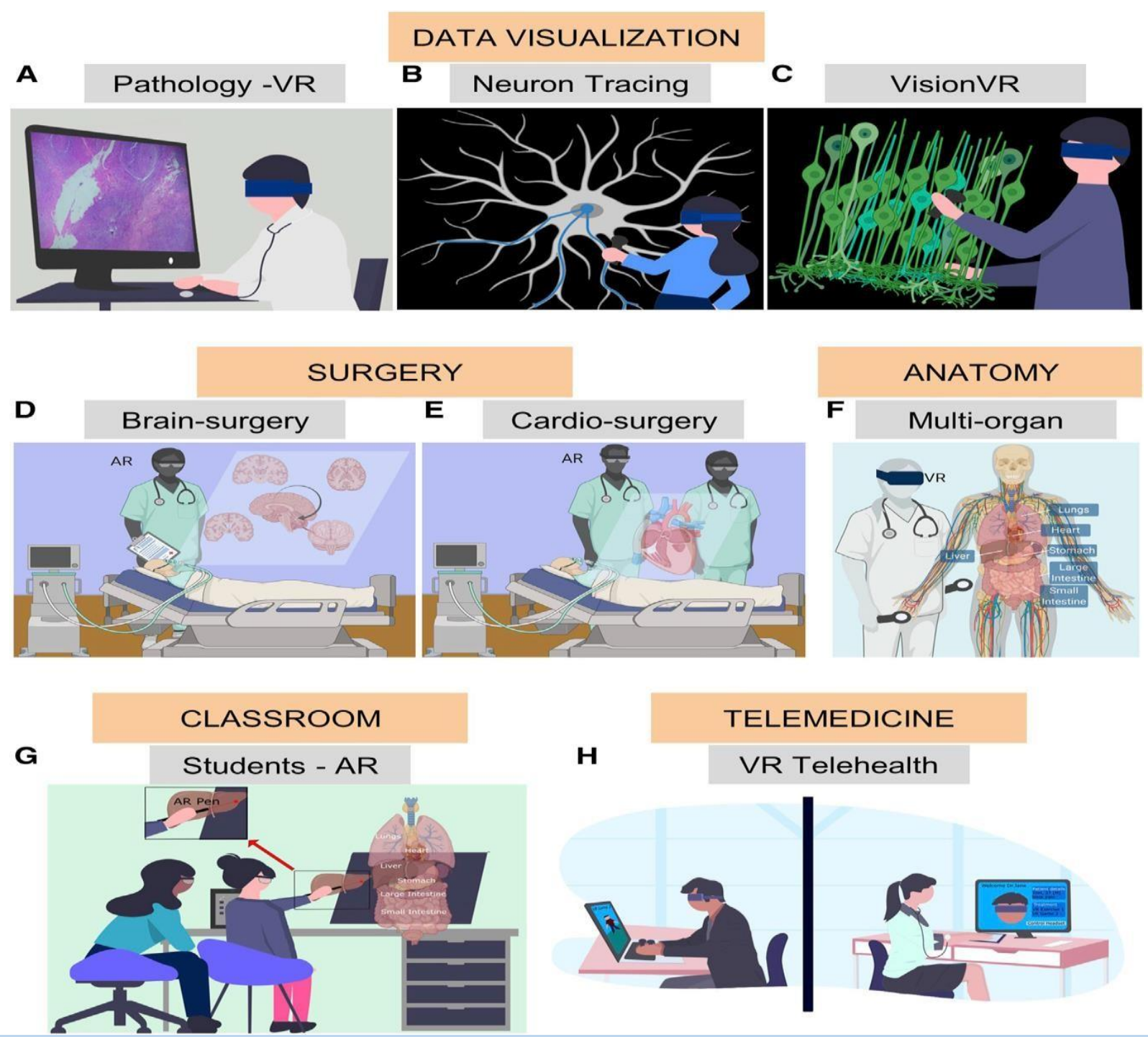

Figure 4: Virtual reality and augmented reality-based visualization of scientific experimentalimaging data, tools for surgery and anatomy, and collaborative interfaces for education andtelehealth [7].

For virtual training of surgeons and biomedical devices

Surgeons require specific skills requiring extreme practice and dedicated training, but this process can be difficult for medical trainees. Virtual reality offers students the op- portunity to perform a low-risk procedure before performing surgery on an individual to resolve this problem.

Students develop skills such as on-site thinking, problem-solving in a hands-on envi- ronment, and performing tasks in a stressful environment. Virtual reality-based training has unique advantages. VR makes it easier to work with various deep organs that may be physically obstructed by others and, therefore, difficult to observe during conventio- nal surgical training VR can be used as a training approach to transfer procedural knowledge in the bio- pharmaceutical industry, replacing traditional reading of long manuals [8].
Experiential biomedical education tools for teaching

Virtual reality enhances the learning experience of students by teaching new concepts of molecular biology in cancerology [7-8]. For a generation living a digital lifestyle, at- tention span has dramatically decreased thanks to media technologies [2-7].

VR as an educational tool offers feasible digital solutions to this problem as students focus on a virtual space where distractions are greatly reduced. One approach to using virtual reality in classrooms is to provide students with headsets synchronized with a central device to experience the same content. It can also be decentralized, where medical lessons take place in a virtual classroom with students wearing VR headsets and logging in from different locations. 


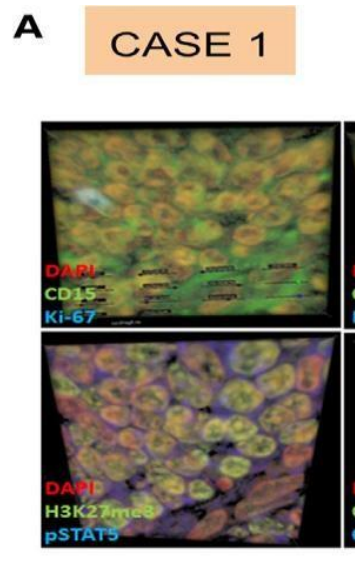

\section{VR-based 3D Multiplex Proteomics \\ Chronic Lymphocytic Leukemia}
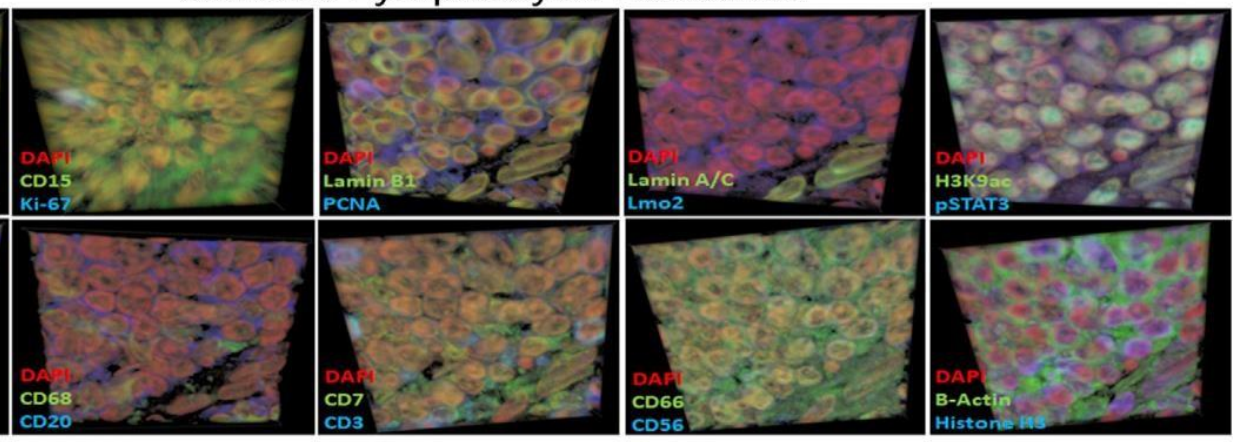

B

\section{CASE 2}

AR-based visualization of a cerebral aneurysm for surgical planning
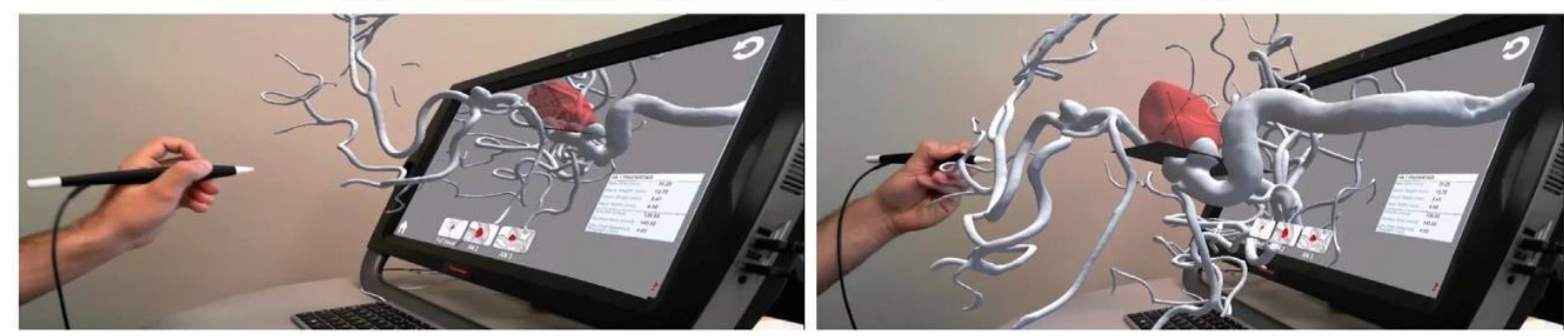

C

\section{CASE 4 Cell Biology with VR-based Education}

Phone Screen

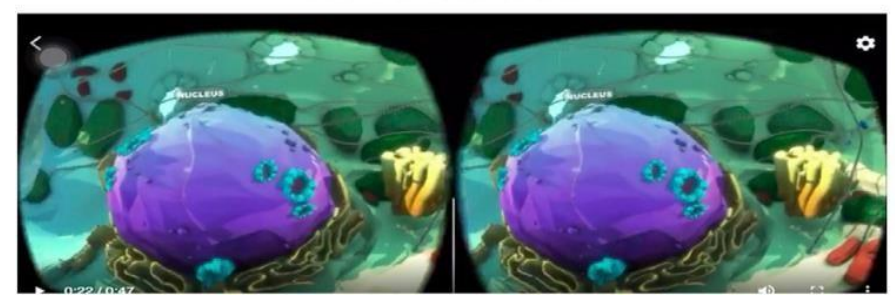

Google Cardboard

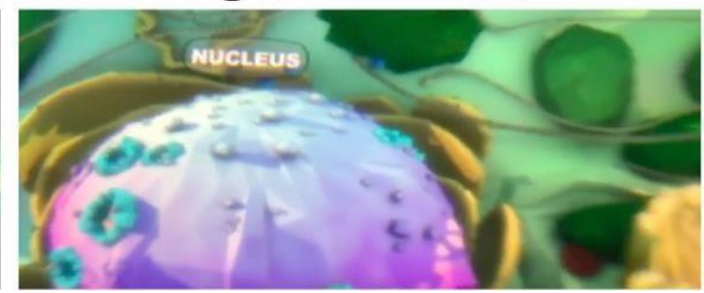

Figure 5: Case studies using virtual reality and augmented reality [7].

\section{Conclusion}

Virtual reality (VR) is revolutionizing the world around us, the use of VR in oncology is today a practice that is increasingly considered by healthcare teams, It is highly inte- ractive, flexible, tailored to the individual, and applicable to people of different ages, genders, and health.

As technology improves and costs are reduced, virtual reality will undoubtedly shape the future of cancer care

\section{References}

1. Medling Uses of Virtual Reality in Healthcare: It's Almost Done. Biomed instrum technol 2005; 39: 16-18

2. Riener R, Harders M. Virtual reality in medicine. London: springer; 2012: 1-2

3. Helfand M, Freeman M. Assessment and management of acute pain in hospitalized adult patients: a systematic review. Pain medicine (Malden, Mass). 2009; 10 (7): 1183-99. Online publication of 13/10/2009.https: // doi.org/ 10.1111 / j.15264637.2009.00718.xPM: 19818030.
4. Turk DC, Wilson HD, Cahana A. Treatment of chronic noncancer pain. Lancet. 2011; 377 (9784): 2226- 35. Online publication 06/28/2011.https://doi.org/10.1016/S01406736(11)60402-9PMID:21704872.

5. Shah A, Hayes C.J., Martin BC Factors influencing long-term opioid use in opioid-naïve patients: a review of initial prescribing characteristics and etiologies of pain. The Journal of Pain: Official Journal of the American Pain Society. 2017; 18 (11): 1374-83. Online publication of 07/18/2017.https://doi.org/ 10.1016 / j. jpain.2017.06.010PMID: 28711636; PubMed Central PMCID: PMC5660650.

6. Dascal J, Reid M, IsHak WW, Spiegel B, Recacho J, Rosen B, et al. Virtual reality and hospitalized patients: a systematic review of randomized controlled trials. Innov Clin Neurosci. 2017; 14 (1-2): 14-21. PMID:28386517; PubMed Central PMCID: PMC5373791.

7. Bin, S., Masood, S. and Jung, Y. (2020). Virtual and augmented reality in medicine. In Biomedical Information Technology, Second Edition, DD Feng, ed. (Academic press), pp. 673- 686. 5. Khor, WS, Baker, B., Amin, K., Chan, A., Patel, K. and Wong, J. 
(2016). Augmented and virtual reality in surgery - the digital surgical environment: applications, limits and legal pitfalls. Anne. Trad. Med. 4, 454.

8. Chirico A, Lucidi F, De Laurentiis M, Milanese C, Napoli A, Giordano A. Virtual reality in health system: beyond entertainment. A mini review on the efficacity of VR during cancer treatment. J Cell Physiol 2016; 231: 275-287.
This work is licensed under Creative

Commons Attribution 4.0 License

To Submit Your Article Click Here: Submit Manuscript

DOI: $10.31579 / 2692-9392 / 0101$
Ready to submit your research? Choose Auctores and benefit from:

$>$ fast, convenient online submission

$>$ rigorous peer review by experienced research in your field

$>$ rapid publication on acceptance

$>$ authors retain copyrights

$>$ unique DOI for all articles

$>$ immediate, unrestricted online access

At Auctores, research is always in progress.

Learn more https://auctoresonline.org/journals/archives-of-medicalcase-reports-and-case-study 